\title{
Microflora of Digestive Tract in Poultry
}

\author{
Rojan I. ALBAZAZ ${ }^{1}$, Emel Banu BÜYÜKÜNAL BAL ${ }^{1 *}$ \\ ${ }^{1}$ KSU, Faculty of Sciences and Letters, Department of Biology, Kahramanmaras/TURKEY
}

\author{
Received (Geliş): 20.06.2014
}

Accepted (Kabul): 07.07.2014

\begin{abstract}
The gut flora are microorganisms that normally live in digestive tract and can do a number of benefit functions for their host health and growth. The unicellular microorganisms are bacteria (predominant), fungi and protozoans. The intestine divided into three parts: the duodenum and small intestine where the number of bacteria relatively low, $<10^{8} \mathrm{~g}^{1}$, the caeca where the microbial fermentation occurs and the number of bacteria present is approximately $10^{11} \mathrm{~g}-1$ (wet weight) and the large intestine which in most bird is relatively short and is a posterior extension of the small intestine beginning at the level of the caeca and opening into the cloaca. In chicken, bacterial activities are mainly found in crop, caeca and, to lesser extent, the small intestine. The $\mathrm{pH}$ and transit time of different section of chicken allow establishment of specific microbial population in chicken. The composition of microorganisms in the gut is not stable over time and not homogeneous among species, individuals, and different parts of the intestine. Development of the gut microflora is dynamic, and is influenced by parents, environment and age. In poultry, the gut microbial community composition changes greatly within the first 2-3 weeks of age before stabilizing until 5-6 weeks of age, when a final change in community composition was observed. In this review, several factors affecting intestinal microflora, members of intestinal bacteria in poultry, roles of Lactobacilli in intestinal microflora were discussed.
\end{abstract}

Key words: Intestinal Microflora, Poultry, Lactobacilli

\section{Kümes Hayvanlarında Sindirim Sistemi Mikroflorası}

Özet: Bağırsak florasını oluşturan mikroorganizmalar normalde sindirin sisteminde yaşarlar ve konakçılarının sağlığı ile büyümesi üzerinde yararlı etkiler oluştururlar. Burada bulunan tekhücreli mikroorganizmalar dominant durumdaki bakteriler ile birlikte fungus ve protozoalardır. Üç ana kısımdan oluşan bağırsakta; duedonum ve ince bağırsakta bakteri sayısı oldukça azdır $<10^{-8} \mathrm{~g}$. Mikrobiyal fermantasyonun daha çok gerçekleştiği sekumda $10^{11}$ g-1 (yaş a ğırlık) kadar bakteri bulunurken, çoğu kanatlıda oldukça kısa olan kalın bağırsak ince bağırsağın posterior bir uzantısı olup, sekumla başlayıp kloakla sona ermektedir. Kanatlıların farklı sindirim sisteminin farklı bölümlerindeki $\mathrm{pH}$ ve içeriğin geçiş zamanı özgün mikrobiyal popülasyonun oluşmasını sağlamaktadır. Bağırsaktaki mikroorganizmaların kompozisyonu her zaman stabil olmayıp, bununla birlikte farklı bağırsak kısımlarında türler ve bireyler içinde homojen değildir. Bağırsak miroflorasının oluşumu dinamik olup, çevre ve yaş gibi faktörlerce etkilenmektedir. Kanatlılarda mikrobiyal kominite kompozisyonu ilk 2-3 haftalık dönemde fazla miktarda değişmekte ve son değişikliğin görüldüğü 5-6 haftalık dönemde stabil hale gelmektedir. Bu derlemede, bağırsak florasını etkileyen bazı faktörler, kanatlılarda bağırsak bakterisi üyeleri ve Lactobasillerin bağırsak florasındaki rollerine değinilmiştir.

Anahtar Kelimeler: Bağırsak Mikroflorası, Kümes Hayvanları, Laktobasil

\section{INTRODUCTION}

It has been reported that the microbial communities present in the gastrointestinal track of poultry are influenced by a number of factors including stocking density, diet, feeding practices, housing conditions, age of birds and pathogens (Torok et al., 2007). Disease and nutritional changes may also have effects on microflora population in different section of intestine. Even though bacterial ecosystems among flocks tend to be similar, quantitative and qualitative differences exist among individuals even if raised in the same pen with a common source of feed and water. Also it is very well established that bacterial communities change radically between the different anatomical segments of the digestive tract. Due to the complexity of the interactions affecting simultaneously the intestinal ecosystem, it is difficult to evaluate the outcome of individual actions. The microorganism of digestive flora may be located in the lumen of intestine, carried by the mucus layer that can form very important cell layers (Fuller, 1984). Large numbers of chicken gut bacteria are gram positive and mainly include facultative anaerobes from the crop to the terminal ileum (Fuller, 1984; Gong et al; 2002). Like other animals, poultry also possesses a specialized organ (ceca) at the terminal part of the gastrointestinal tract to offer nutrient rich habitat for the millions of microflora $\left(10^{11} \mathrm{CFU} / \mathrm{g}\right.$ belonging to 200 or more strains) and to take benefits of synergism from microbial fermentation. The microflora of the poultry caecum is broadly categorized into three: dominating, sub-dominating and temporary populations (Barnes, 1979). On the first day of chick's life, the major caecum

*Corresponding author: Büyükünal Bal, E.B., banubal@ksu.edu.tr 
microflora includes species of Enterobacteriaceae, Enterococcus and Lactobacillus. Bacteriodes and Eubacterium spp. got established after second weeks of chick's age (Van der Wielen et al., 2001). The microflora of the poultry gut is presumed to play multidimensional role including digestion, metabolism, pathogen exclusion, immune stimulation, vitamin synthesis etc. (Timms, 1968; Nurmi and Rantala, 1973; Coates, 1980; Fuler, 1984; Mead, 1989; Mulder et al., 1997; Salminen et al., 1998). The flora is also involved in the development of the intestinal immune system (Gabriel et al., 2006). In general, the use of low doses of antibiotics decreases the number of the most susceptible bacterial communities and enhances the growth of the resistant bacteria. Nutritional composition of feed and thus local availability of raw materials as well as seasonal changes will impact the intestinal flora.

Through the years, the assessment of microbial populations has relied on in vitro culture techniques using selective or non-selective media. One of the main disadvantages of culture-based method is that it can only assess culturable microorganisms (Barnes et al., 1972; Bjerrum et al., 2006). Recently, other cultureindependent methods that rely on molecular techniques have been developed to study bacterial populations (Gong et al., 2002; Amit-Romach et al., 2004; Bjerrum et al., 2006; Pissavin et al., 2012). By the aid of modern approaches including T-RFLP (terminal restriction fragment length polymorphism) analysis, 16S rRNA gene analysis, capillary electrophoresis single-strand conformation polymorphism (CE-SSCP) we have learnt that there are many species of bacteria that we are not able to grow in vitro, including many unknown genera of bacteria. Actually, it has been estimated that less than $25 \%$ of the intestinal bacteria have been cultured. Consequently, when analyzing intestinal bacterial populations we must consider that we are observing a modest portion of the real ecosystem and conclusions drawn from diverse studies must be taken carefully (http://www.worldpoultry.net).

\section{Effects of antibiotics on intestinal microflora}

The use of antibiotics as therapeutic or preventive doses impacts chickens of different ages differently. For example, three day old birds treated with bacitracin and virginiamycin at 4.4 and $11 \mathrm{ppm}$, respectively, increased L. salivarius while $22 \mathrm{ppm}$ of virginiamycin almost completely inhibited the presence of these bacteria in the ileum of chickens. Similarly, treatment with antibiotics such as growth promoters also increased the numbers of Enterococcus sp. in the same experiment (Zhou et al., 2007). On the other hand, virginiamycin at 11 and $22 \mathrm{ppm}$ inhibited L. salivarius in two week old chickens. Lactobacillus population decreases in the ileum of two and three week old broilers fed with a diet supplemented with salinomycin $40 \mathrm{ppm}$ and avilamycin 10 ppm (Lorenzoni, 2011).
In birds raised without antibiotics the number of $C$. perfringens seems to increase with age; salinomycin 40 ppm and avilamycin $10 \mathrm{ppm}$ decrease the number of $C$. perfringens and this effect seems more pronounced when the diet is supplemented with soy oil than with lard and tallow. It has been noted that tylosin phosphate (100 ppm) increases the number of Lactobacillus gasseri in detriment of $C$. perfringens, which was detected in higher numbers in control birds (Lorenzoni, 2011). Feed withdrawal also impacts bacterial population in the small intestine. It has been determined that the longer the feed withdrawal is the more severe the decrease in bacterial uniformity, assessed by a reduction in the number of bacterial species detected (Lorenzoni, 2011).

Pedroso et al. (2006) treated broilers with antibiotics (avilamycin, bacitracin methylene disalicylate, and enramycin) that are raised either in battery cages or in floor pens. They found that all antibiotics induced changes in the composition of the intestinal bacterial community of the birds in both experiments. The number of bacterial genotypes found in the intestinal tract of chickens was not reduced by the antibiotics supplemented in either environment. However, the changes in the composition of the intestinal bacterial community induced by antibiotics may be related to improvement in growth performance.

\section{Members of intestinal bacteria in poultry}

Among three regions of the gastro intestinal tract (duodenum, jejunum-ileum and cecum), the duodenum has the lowest population of bacteria and the cecum the highest. Using molecular techniques, no significant difference was detected between the bacteria present in the ileum and ceca at three days of age with a large proportion of the bacteria corresponding to Lactobacillus. In chickens, cecal counts of Lactobacilli average $1 \times 10^{9}$. Using traditional microbiological techniques, along with Lactobacilli, large amounts of Enterobacteriaceae and Enterococci were found.

In the ceca of juvenile birds, the bacterial population is different from that found in the small intestine. Actually, as early as three days of age the number of Enterobacteriaceae and Enterococci start to decline probably due to the increase in volatile fatty acids (acetate, butyrate, and propionate) in the ceca. Starting at 12 days of age the total count of facultative anaerobic and obligate anaerobic bacteria is 10 to 15 times greater than that of aerobic bacteria, accounting for as many as $1.6 \times 10^{11} / \mathrm{g}$ of dry tissue. The majority of the anaerobic bacteria corresponded to Gram-positive bacteria. By two weeks of age the concentration of volatile fatty acids and Enterobacteriaceae and Enterococci stabilise in the ceca. In the ceca $65 \%$ of the isolated rRNA sequences corresponded to Clostridiaceae. Other abundant bacterial sequences corresponded to Fusobacterium (14\%), Lactobacillus (8\%) and 
Bacteroides (5\%). Zhu et al. (2002) reported that the ceca of mature birds fed a standard commercial diet was mainly populated by Clostridium leptum (20\%), Clostridium coccoides (27\%), Sporomusa sp. (21\%), and Gamma Proteobacteria groups (20\%). It was also determined that Atopobium, Bacteroides, and Bifidobacteria accounted for 3.6, 2 and $1 \%$ of the bacterial population, respectively.

Smith (1965) and Barnes et al. (1972) reported Streptococcus, Lactobacilli and E. coli as the major types of bacteria found in the duodenum and ileum of 2week old chicks. Salanitro et al. (1978) found that majority of the intestinal bacteria (60 to 90\%) in 2 week-old chick was belonged to those three bacterial groups. They also reported that the small intestine was inhabited by diverse bacterial types such as Eubacterium, Propionibacterium, Clostridium, Gemmiger and Fusobacterium, but those are occured in lesser number.

Dietary protein source and level of inclusion affect the numbers of $C$. perfringens in ileum and ceca. In general terms, the increment of crude protein levels in poultry diets is correlated with an increase in $C$. perfringens in fishmeal-base diets (which are higher in glycine and methionine than soy based diets). This correlation however, is not always found in birds consuming a soy-based diet. It has been established that housing conditions also impact bacterial population in poultry.

Bacteria which are normally pathogenic for poultry, like Clostridium, were isolated from young birds Salmonella, Campylobacter, and E. coli can be regularly isolated from healthy individuals in older birds. In fact these bacteria do not produce intestinal disturbances in most of the cases could be attributed to a healthy balance of the intestinal microflora. In fact, in poultry, enteric disorders are routinely reported after the normal microflora is disturbed by antibiotic treatment.

\section{Roles of Lactobacilli in intestinal microflora}

Lactobacilli establish in the crop after a few days of hatching. Depending on the time that the feed remains in the crop, Lactobacilli may have some influence in microbial fermentation. The passage from the crop to the small intestine involves drastic changes in the luminal environment. By means of $\mathrm{pH}$ variation and enzymatic action the pro-ventricle plays a significant role as a chemical barrier against pathogens. Actually, E. coli, and Campylobacter have been found in higher numbers in the crop than in the gizzard. In broilers fed a corn-soy based diet deprived of antibiotics and additives, nearly $70 \%$ of the rRNA sequences found in the ileum corresponded to Lactobacillus.

A population of Lactobacillus is present in birds of two days of age and it remains without drastic changes until market age. The main species of Lactobacillus present in chicken intestine are $L$. acidophilus, $L$. salivarius, and L. fermentum. Host specificity has been described for Lactobacillus, in fact, the small intestine of germ free chickens is not effectively colonised by human stains of L. acidophilus.

It is also important to note that not all Lactobacilli have the same properties; actually important differences like bacteriocin production are often single-strain characteristics and thus extra benefit can be achieved by using probiotic strains that are known to possess a particular feature (Kizerwetter-Swida and Binek, 2005). Many studies were focused on Lactobacilli strains isolated from chicken gastrointestinal tract and examined for their potentially probiotic properties towards their inhibitory activity against poultry enteropathogenic bacteria (Lin et al., 2007; NealMcKinney et al., 2012).

Inulin, being a prebiotic, is not digested by the birds own gastric or pancreatic enzymes but utilized by the specific group of microflora especially Bifidobacteria and Lactobacilli at the large intestine for production of various short chain fatty acids and lactic acids (Adil and Magray, 2012, Samanta et al., 2013). The production of fatty acids such as butyrate and acetate at large intestine lowering of luminal $\mathrm{pH}$. Acidic $\mathrm{pH}$ is found to increase mineral solubility and facilitates higher mineral absorption (Levrat et al., 1991).

\section{CONCLUSION}

Members of bacterial population in gastrointestinal track of poultry vary with many factors including age. Antibiotics, enzymes, prebiotics, probiotics can also alter the dynamics of intestinal bacterial flora in poultry. In general, bacteria inhabits the gastrointestinal track provide a beneficial microenvironment for the host animal digestive physiology since they can metabolize several nutrients that the host cannot utilize and convert them to useful end products such as short-chain fatty acids. Therefore development of the bacterial microflora was determined by competiveness of harmful and beneficial bacteria.

\section{REFERENCES}

Adil, S., Magray, S.N., 2012. Impact and manipulation of gut microflora in poutry: A review. $2012 \mathrm{~J}$. Anim. Vet. Adv., 11:873-877.

Amit-Romach, E., Sklan, D., Uni, Z., 2004. Microflora ecology of the chicken intestine using $16 \mathrm{~S}$ ribosomal DNA primers. Poult. Sci., 83:10931098.

Barnes, E.M., 1979. The nutritional significance of dietary fiber analysis. Anim. Feed. Sci. Technol, 90:3-20.

Barnes, E.M., Mead, G.C., Barnum, D.A., Harry, G.C., 1972. The intestinal flora of the chicken in the period of 2 to 6 weeks of age with particular reference to the anaerobic bacteria. Br. Poultry Sci., 13:321-326. 
Bjerrum, L., Engberg, R.M., Leser, T.D., Jensen, B.B., Finster, K., Pedersen, K., 2006. Microbial community composition of the ileum and cecum of broiler chickens as revealed by molecular and culture-based techniques. Poult. Sci, 85:11511164.

Coates, M.E., 1980. The gut microflora and Growth. In: Growth in Animals, Lawrence (ED.), Butterworths, London, UK, pp: 175-188.

Fuller, R., 1984. Microbial activity in the alimentary tract of birds. Proc. Nutr. Soc., 43:55-61.

Gabriel, I., Lessire, M., Mallet, S., Guillot J.F. 2006. Microflora of the digestive tract: critical factors and consequences for poultry. World Poult. Sci. J. 62:499-511.

Gong, J., Forster, R.J., Yu, H., Chambers, P.M., Sabour, P.M., Wheatcroft, R., Chen, S., 2002. Molecular analysis of bacterial populations in the ileum of broiler chickens and comparison with bacteria in the caecum. FEMS Microbiol. Ecol., 41:171-179.

Kizerwetter-Swida, M., Binek, M., 2005. Selection of potentially probiotic Lactobacillus strains towards their inhibitory activity against poultry enteropathogenic bacteria. Pol. J. Microbiol., 54:287-294.

Levrat, M.A., Remesy, C., Sorensen, P., 1991. High propionic acid fermentation and mineral accumulation in the caecum of rats adapted to different levels of inulin. J. Nutr., 121:1730-1737.

Lin, W.H., Yu, B., Jang, S.H., Tsen, H.Y., 2007. Different probiotic properties for Lactobacillus fermentum strains isolated from swine and poultry. Anaerobe, 13:107-113.

Lorenzoni, G. 2011. Intestinal flora and nutrition demand a true balance. World Poult., 3: 1.

Mead, G.C., 1989. Microbes of the avian cecum: Types present and substrates utilized. J. Exp. Zool., 3:4854.

Mulder, R.W.A.W., Havenaar, R., Huis, J.H.J., 1997. Intervention stragies the use of probiotics and competitive exclusion microfloras against contamination with pathogens in poutry and pigs. In: Probiotics 2 Application and Practical Aspects, Fuller R. (Ed.). Chapman and Hall, New York, pp: 187-207.

Neal-McKinney, J.M., Lu, X., Duong, T., Larson, C.L., Call, D.R., Shah, D.H., Konke, M.E., 2012. Production of organic acids by probiotic Lactobacilli can be used to reduce pathogen load in poultry. PLOS ONE, 7:1-11.

Nurmi, E.V., Rantala, M., 1973. New aspects of Salmonella infection in broiler production. Nature, 241:210-211.
Pedroso, A.A., Menten, J.F., Lambais, M.R., Racanicci, A.M., Longo, F.A., Sorbara, J.O., 2006. Intestinal bacterial community and growth performance of chickens fed diets containing antibiotics. Poult. Sci., 85:747-752.

Pissavin, C., Burel, C., Gabriel, I., Beven, V., Mallet, S., Maurice, R., Queguiner, M., Lessire, M., Fravalo, P., 2012. Capillary electrophoresis single-strand conformation polymorphism for the monitoring of gastrointestinal microbiota of chicken flocks. Poult. Sci., 91 :2294-2304

Salanitro, J.P., Lake, I.G.B., Muirhead, P.A., Maglio, M., Goodman, R., 1978. Bacteria isolated from the duodenum, ileum, and cecum of young chicks. Appl. Environ. Microbiol., 35:782-790.

Salminen, S., Bouley, C., Boutron-Ruault, M.C., Cummings, J.H., Frank, A., 1998. Functional food science and gastrointestinal physiology function. Br. J. Nut., 80:147-171.

Samanta, A.K., Jayapal, N., Senani, S., Kolte, A.P., Sridhar, M., 2013. Prebiotic inulin: Useful dietary adjuncts to manipulate the livestock gut microflora. Brazilian Journal of Microbiology, 44:1-14.

Smith, H.W., 1965. Observations on the flora of the alimentary tract of animals and factors affecting its composition. J. Pathol. Bacteriol., 89:95-122.

Timms, I., 1968. Observations on the bacterial flora of the alimentary tract in three age groups of normal chickens. Br. Vet. J., 24:470-477.

Torok, V.A., Ophel-Keller, K., Hughes, R.J., Forder, R., Ali, M., Macalpine, R., 2007. Environment and age: impact on poultry gut microflora. Proceedings ofthe 19th Australian Poultry Science Symposium, Sydney, New South Wales, Australia, 12-14 February. pp 149-152.

Van der Wielen, P.W., Biesterveld, S., Notermans, S., Hofstra, H., Urlings, B.A.P., Van knapen, F., 2001. Inhibition of glucose limited sequencing fed batch culture of Salmonella enteric Setrovar Enteritidis by volatile fatty representative of the ceca of broiler chickens. Appl. Environ. Microbiol., 67:1979-1982.

Zhou, H., Gong, J., Brisbin, J.T., Yu, H., Sanei, B., Sabour, P., Sharif, S., 2007. Appropriate chicken sample size for identifying the composition of broiler intestinal microbiota affected by dietary antibiotics, using the polymerase chain reactiondenaturing gradient gel electrophoresis technique. Poult Sci., 86:2541-2549.

Zhu, X.Y., Zhong, T., Pandya, Y., Joerger, R.D., 2002. 16S rRNA-based analysis of microbiota from the cecum of broiler chickens. Appl. Environ. Microbiol., 68:124-137. 